\section{CZECH PENSION REFORM: HOW TO RECONCILE EQUIVALENCE WITH FISCAL DISCIPLINE}

\author{
Martin Potůček and Veronika Rudolfová \\ Charles University in Prague
}

Abstract: One of the recent changes in the Czech Republic's pension system was provoked by a petition to the Constitutional Court. The setting of bend points for determining the amount of pensions depending on the insured person's previous earnings was contested as discrimination against higher income categories. The Constitutional Court granted the petition. The result was an approval and implementation of an amendment to Act No. 155/1995 Coll., on Pension Insurance, that for the purposes of calculating the level of old-age pensions favoured the highest income decile at the expense of most other insured persons, namely those with middle incomes. Simultaneously, the political criterion of fiscal discipline was applied to ensure the financial sustainability of the pension system. In analysing this case, we critically adopt the theory of actor-centred institutionalism and the theory of the policy cycle. From the nature of the analysed case it follows that we pay attention mainly to the legislative process which resulted in the amendment. Our methodology is dominated by analysis of documents (legal norms, court decisions, political programmes, official publications) and political and administrative communication (including debates on legislative drafts in the executive and legislature).

Keywords: pension reform, Czech Republic, equivalence principle, pension system, actor-centred institutionalism, policy cycle

MARTIN POTU゚ČEK - Center for Social and Economic Strategies, Faculty of Social Sciences, Charles University in Prague, Smetanovo nábř. 6, 11000 Praha 1, Czech Republic•potucek@fsv.cuni.cz

Central European Journal of Public Policy

Vol. 9 - № 1 - May 2015 - pp 170-195

ISSN 1802-4866

@ 2015 Martin Potũček, Veronika Rudolfová

Licensed under Creative Commons Attribution 3.0

\section{INTRODUCTION}

With the emergence of an independent Czech Republic in January 1993, the Act on Social Security Premium and Contribution to the State Employment Policy (No. 589/1992 Coll.) came into force. Pension insurance premiums were introduced as special compulsory payments outside the scope of the tax system in order to emphasise the merit-based nature of the Czech pension system.

Subsequent years saw a number of parametric adjustments related to indexation, retirement age, periods for which premiums are paid by the state, and contributory periods. Although there were discussions on the need of a fundamental reform of the pension system in both the political arena and professional circles, there was a lack of lasting political consensus to adopt a socalled paradigmatic reform of the pension system.

Public pension expenditures in the Czech Republic amount to around 10\% of GDP. Prior to its reforms, the Czech pension system ranked among the most solidary systems in the OECD. Its Gini coefficient on a model income distribution had a value of $9.1 \%$ (the OECD average is $18 \%)^{1}$. With respect to the adequacy of pensions, the Czech Republic's system is comparable to other OECD countries. The following two tables show the pension replacement rates, according to OECD statistics (OECD, 2013), for the country and for the OECD as a whole.

Table 1 Gross pension replacement rates by earnings

\begin{tabular}{lllll}
\hline Level of earnings & Median & $0.5 \times$ mean & $1 \times$ mean & $1.5 \times$ mean \\
\hline Czech Republic & 59.9 & 85.2 & 52.2 & 41.2 \\
\hline OECD & 57.9 & 71.0 & 54.4 & 48.4 \\
\hline
\end{tabular}

Source: OECD, 2013.

Table 2 Net pension replacement rates by earnings

\begin{tabular}{lllll}
\hline Level of earnings & Median & $0.5 \times$ mean & $1 \times$ mean & $1.5 \times$ mean \\
\hline Czech Republic & 73.4 & 99.1 & 64.7 & 51.6 \\
\hline OECD & 69.1 & 81.7 & 65.8 & 59.7 \\
\hline
\end{tabular}

Source: OECD, 2013.

On 13 April 2007, the Constitutional Court received a petition in which the Regional Court in Ostrava sought the annulment of the provisions of part of Sec-

1 Source: MoLSA 
tion 15, second sentence, of Act No. 155/1995 Coll., on Pension Insurance, that concerned the setting of bend points for determining the amount of pensions depending on the previous earnings of the insured. The petition was related to the case of JUDr. K.S. who, before the Regional Court in Ostrava, contested the amount of pension granted to him and pointed to the fact that the total amount of the pension granted accounts for only a small part of his income, which he does not consider to be adequate material security as guaranteed by the Charter of Fundamental Rights and Freedoms.

The plaintiff had worked as a judge; the average salary of this profession is several times higher than the average salary in the country. He was dissatisfied with the percentage assessment and although he agreed that it was determined in accordance with applicable law, he complained that it accounted for only $19 \%$ of his previous income, while the average replacement rate was about $44 \%$ of gross wage in 2004. He referred to Article 30 Paragraph 1 of the Charter of Fundamental Rights and Freedoms which, as a part of the Czech constitutional order, stipulates that "citizens have the right to adequate material security in old age and during periods of work incapacity, as well as in the case of the loss of their provider." According to the plaintiff, the income reduction for the purposes of calculating the percentage assessment of his pension disadvantages him and places him in an unequal position. He thus contested the provision of the Section 15 of the Act on Pension Insurance as unconstitutional, arguing that it discriminates against insured persons with higher in comes. He referred to the fact that even the name of the Act indicates that it involves insurance, i.e. a legal institution that has its settled content, while premiums should not be treated as taxes. For insurance, there should be a clear and proportionate link between the contributions paid and the pension received. There was an interesting argument against solidarity as a justification for setting the bend points and different treatment of different categories of insured persons. According to the petitioner, the principle of solidarity in itself does not give rise to certain rights and obligations. Solidarity, according to the petitioner, is ensured sufficiently in the fact that insurance premiums are consistently based on the level of pay.

\section{The contested provision - Section 15 of Act No. 155/1995 Coll. on Pension Insurance - in the original wording as of 2009}

The calculation base equals the personal assessment base (Section 16) provided it does not exceed CZK 10,500. If the personal assessment base exceeds CZK 10,500, the calculation base is determined as follows: the sum of CZK 10,500 is counted in full; the amount of the personal assessment base of over CZK 10,500 and up to CZK 27,000 is reduced to $30 \%$; and any amount of the personal assessment base over CZK 27,000 is reduced to $10 \%$.

The plaintiff thus contested the degree of equivalence of the pension system i.e. the ratio between the pension benefits calculated and previous work-related income, which he perceived as insufficient.

\section{GOAL OF THE PAPER}

We offer a detailed analysis of the decision-making process with regard to two conflicting criteria of the pension reform: strengthening the equivalence of pensions compared to previous contributions, on one hand, and keeping public pension expenditures under control, on the other. Such an analysis has to take into account the complex legal, political, and institutional environment of the Czech Republic at the beginning of the second decade of the 21st century.

\section{THEORY AND METHODS}

In order to understand the policy process from lodging the petition to the Constitutional Court to adopting the amendment to the Act on Pension Insurance to implementing it in practice, we proceed as follows. First, we apply the perspective of actor-centred institutionalism. We briefly characterise the main institutions and actors that were involved in that process. Then we try to identify the actor constellation and modes of interaction leading to the political decisions. We supplement this analysis by decomposing the policy process into its individual stages. In the conclusion, we assess to what extent our analytical approach to the pension reform case proves to be useful.

From the nature of the analysed case it follows that we pay attention mainly to the legislative process which resulted in the amendment to the rel- 
evant legal norm. Within the scope of the adopted methods there dominates analysis of documents (legal norms, court decisions, political programmes, of ficial publications) and political and administrative communications (including debates on legislative drafts at the levels of the government, the parliament and the president of the Czech Republic).

\section{Actor-centred institutionalism}

The theory of actor-centred institutionalism by Renate Mayntz and Fritz Scharpf (Mayntz \& Scharpf, 1995; Scharpf, 1997) assumes that the behaviour of policy actors is significantly, though never entirely, determined by existing (either formalised or informal) institutions, which influence their perceptions, preferences and available resources. Such significant determination is given also by the power of actors' expectations that other actors will also act in accordance with these institutions. The theory further assumes that individuals interacting within formalised institutions are governed by their internal rules "Rules and systems of rules in any historically given society not only organize and regulate social behaviour but make it understandable-and in a limited condi tional sense-predictable for those sharing in rule knowledge." (Burns, Baumgartner \& Deville, 1985, p. 256, quoted in Scharpf, 1997, p. 40)

\section{Actors' behaviour}

Imported from economics, the normative assumption of rational choice theory is that the decision maker should choose the option that results in the highest utility (Jaeger et al., 2001). When the preferences of more than one actor are involved, the Pareto optimality criterion is used. Actor-centred institutionalism avoids the extreme assumptions of neoclassical economics. In contrast to the homo economicus model of individual behaviour that assumes "rational choice" in terms of maximizing individual utilities, actor-centred institutionalism uses the term "bounded rationality" (Scharpf, 1997). Actors do not seek to strictly maximize but rather satisfy their needs according to disposable in formation and their own cognitive capabilities. The concept of bounded rationality is related to what Scharpf terms "intentional actors" (1997, also cited in Korpi, 2001).

Composite actor is defined by Scharpf (1997) as "an aggregate of individuals" that has "a capacity for intentional action at a level above the individuals involved" (Ibid: 52), i.e. an organization. The problem of composite actors acting on behalf of or in the name of a group or organisation (Scharpf, 1997) is that their preferences are not only a sum of members' self-interests, but also include shared norms and identities. The composite actor can be perceived as an actor per se or as an institutional structure. Therefore, on one hand, rational choice theory is not always easy to apply. On the other hand, even what appears as irrational behaviour (or Scharpf's bounded rationality) at first sight can be explained using rational choice theory (Rahmatian \& Hiatt, 1989). Actors may be misinformed (some of their factual beliefs are false), mistaken (some of their causal beliefs are false), or misguided (some of their evaluative beliefs are false) (Bots, 2008).

The theory works with two specific concepts. An actor constellation is a structure of actors involved, their strategic options and outcome preferences, and the outcomes associated with the combinations of those strategies and preferences. An actor constellation has a specific pattern of potential conflicts and their possible solutions, of whether actors may achieve their preferred solutions through coordination of their policies or rather through mutual competition (Ovseiko, 2002). However, the concept of actor constellation offers only a static image of the running interaction which results in public policy outcomes. These processes may vary considerably and can be described as different modes of interaction. There are four different modes: unilateral action, negotiated agreement, majority choice and hierarchical direction. In the latter mode, the strategy of remaining players is determined by decisions of an actor placed hierarchically on a higher position (Scharpf, 1997). Scharpf's conceptualization is summarized in Figure 1.

Figure 1 Public policy research on the relationship of actors and institutions

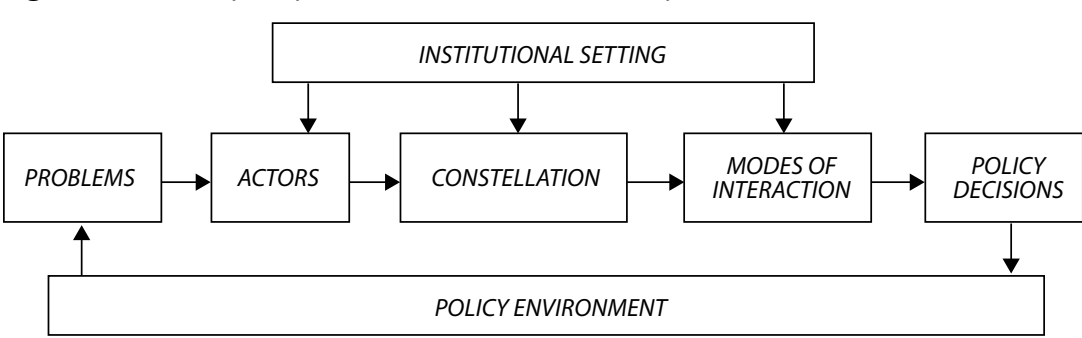

Source: Scharpf, 1997, p. 44.

Specifying the actors and institutions involved is usually only the first step towards better understanding a given public policy. Neither can their modes of interaction reveal enough to fully comprehend the course of the entire process. The policy process occurs at multiple levels, the relationships of actors and institutions tend to change, and the given public policy depends on other policies together with external context. Therefore, it is necessary to resort to concep- 
tual frameworks that attempt, even at the cost of simplification, to capture this variability in time. The phase model of the policy cycle is one of the oldest tools used for that purpose.

\section{The theory of the policy cycle}

Lasswell (1956) divided the course of the process of public policy into several (in his case seven) stages - separated and sequential steps. This was followed by other authors with a series of different ideas about the number, nature and content of these individual steps. The debate was also joined by serious critics of this approach. Lindblom (1968) was one of the first who pointed out that the boundaries between these phases are somewhat obscure. Schlager 11999 , in Hupe, Hill, 2006) saw the usefulness of phasing in the categorisation of behaviour, decision making and actions within the policy process as a whole. Hupe and Hill (2006) themselves opined that the phase approach is rather a conceptual framework than a full-fledged theory. The traditional phase model "may register a development trend, but it is not able to analyse and explain it." (Winkler, 2007, p. 29) In our discussion we restrict ourselves to a simple four-component model, as depicted in Figure 2. In the following section, we will proceed to identifying key institutions and actors.

Figure 2 The phase model of the policy process

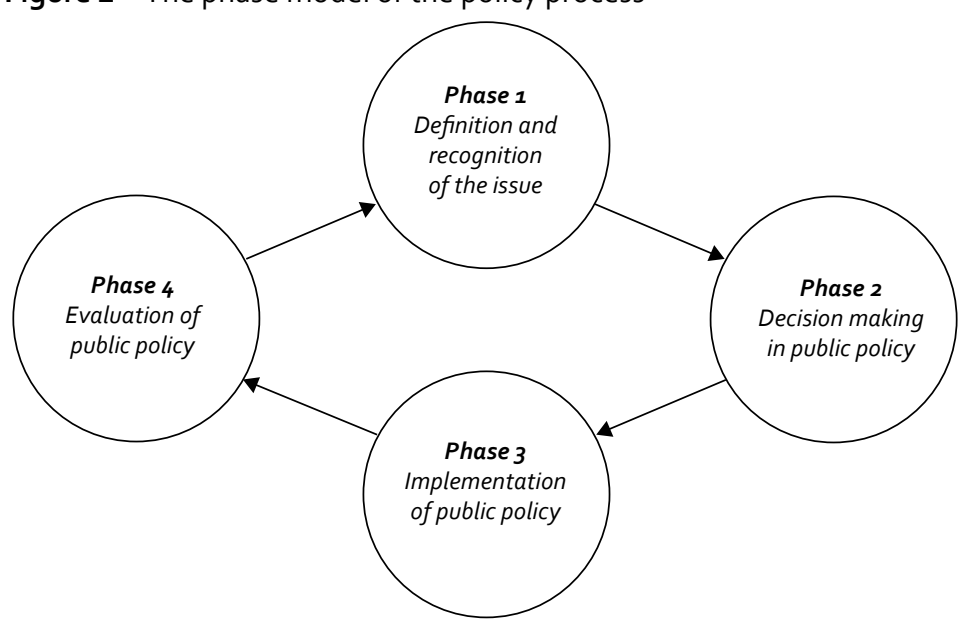

Source: Howlett \& Ramesh, 1995. Modified.

\section{ANALYSIS - INSTITUTIONS AND ACTORS}

\section{Institutions}

The constitutional order of the Czech Republic is a set of constitutional acts and documents of constitutional relevance. It consists of the Constitution of the Czech Republic of 1992, the Charter of Fundamental Rights and Freedoms of 1991 and constitutional acts adopted pursuant to the Constitution.

The Constitutional Court is a judicial body protecting constitutionality pursuant to Section 83 of the Constitution of the Czech Republic. Its judgments are final and cannot be appealed. The Constitutional Court decides in situations when there is a breach of fundamental human rights and freedoms guaranteed by the constitution.

The Parliament of the Czech Republic is the bicameral national legislature. It consists of the Chamber of Deputies (200 members elected using a proportional representation system) and the Senate (81 senators elected using a majoritarian electoral system)

The President of the Czech Republic has minimal executive powers. S/he has the right to turn back an Act adopted by the Parliament of the Czech Republic. The so-called suspense veto does not apply to constitutional acts and acts subject to shortened debate under legislative emergency or state of war. The president must justify his/her veto. Pursuant to the procedural rules of the Chamber of Deputies, the President shall not sign an Act against which s/he has unsuccessfully used the right of veto.

\section{Actors}

\section{The plaintiff}

Citizen JUDr. K.S., former judge, challenged the degree of equivalence of the pension system as inadequate in terms of discrimination against insured persons with higher incomes (in violation of the Charter of Fundamental Rights and Freedoms).

\section{The Government of the Czech Republic}

The decision of the Constitutional Court was made public on 16 April 2010, in the run-up to early parliamentary elections in which the pension reform played the role of an important campaign issue. The elections to the Chamber of Deputies were held on 28-29 May 2010 and resulted in the formation 
of a right-centre government coalition of the Civic Democratic Party, TOP 09 and "Public Affairs". ${ }^{2}$ The preparation of a solution to which the Constitutional Court committed the executive power took place following the elections. It was a period of a continuing global financial crisis, in which the Czech Republic was as well affected by economic depression, rising unemployment rates and growing deficits of the state budget. The government reacted by declaring radical restriction of public expenditures its highest priority.

The Ministry of Labour and Social Affairs of the Czech Republic (MoLSA)

The MoLSA- prepared alternative proposals for a solution. It was the only actor to do so. Two solutions were basically unworkable; the so-called zero variant would abolish the principle of equivalence in the pension system and go completely against the spirit of the decision of the Constitutional Court and the second variant, replacing the system of insurance by a system of social security, could not be accomplished under given time constraint. The third option, the so-called substantive solution, was elaborated in three variants. Potential impact on the pension account's balance became the main assessment criterion. With regard to the priority of fiscal discipline, the MoLSA finally recommended the variant of structural adjustments only to the expenditure side of the pension account, without any additional demands for revenues.

\section{The Research Institute of Labour and Social Affairs}

The Research Institute of Labour and Social Affairs provides analytical capacities for the MoLSA. In the case of the so-called Minor Pension Reform, it published analyses on the decision of the Constitutional Court and the degree of equivalence of the pension system, including proposals of possible solutions (Holub, 2010a, Holub, 2010b)

\section{Political parties}

The coalition parties (Civic Democratic Party, TOP 09, Public Affairs), although presenting the legislative proposal as enforced by the decision of the Constitutional Court, had accentuated in their election programmes as well as in the government policy statement fiscal unsustainability of the pension system and promoted, among other things, strengthening the degree of equivalence through compulsory saving in private pension funds.

2 See section on the decision-making phase below for more details
The opposition parties, the Czech Social Democratic Party and the Communist Party of Bohemia and Moravia, criticised the decision of the Constitutional Court, primarily due to concerns about weakening the degree of solidarity and its position in the pension system. The Czech Social Democratic Party argued the decision was "not to be under the authority of the Constitutional Court". The Communist Party of Bohemia and Moravia argued the decision essentially abolished solidarity in the pension system.

\section{Social partners}

The position and strength of social partners within a political system depends on the country's historical tradition and political culture. Traditionally the strongest positions have been assumed by social partners in countries which perceive social partnership as crucial. Corporatist countries exhibit a high degree of institutionalisation of social partners and a key role of social dialogue in the workings of the political system (e.g., Austria). In other countries, the relationship between social partners and the state has no impact on the functioning of the political system and social partners de facto no longer participate on policy decision making. Social dialogue is not institutionalised and the partners do not have functionally formalised ways of how to influence the decision making processes. They in turn use lobbying and various other methods to influence and appeal to the public. However, this situation is not typical among EU states and concerns especially the UK and possibly also Greece.

In the Czech Republic, tripartism constitutes a firm, integral part of the political system, though the configuration of the governing coalition affects the position and power of social partners. The changes proposed under the socalled Minor Pension Reform were consulted within the Plenary Session of the Council of Economic and Social Agreement. The status of the Council is not legally regulated.

The Czech-Moravian Confederation of Trade Unions was the strongest opponent of the decision of the Constitutional Court of all the social partners. In accordance with its fundamental values, it negatively perceived mainly the strengthening of the degree of equivalence at the expense of solidarity: "The proposed solution will, in the future, worsen the pension rights of $80 \%$ of citizens in favour of a higher income for the richest 10\%." (Czech-Moravian Confederation of Trade Unions, 2011, p. 1). The Confederation presented at the Council of Economic and Social Agreement meeting its own, socially more sensitive design of the pension reform, which would not lead to a reduction of the newly calculated pensions. 
The Confederation of Industry of the Czech Republic concurred with the solution as proposed and submitted by the MoLSA while adding that it would prefer a higher ceiling to the premiums. Instead of the level of three times the average wage, it suggested four times (that was, of course, an adjustment to the revenue side, while the government in its response to the decision of the Constitutional Court designed only modifications to the expenditure side)

\section{Czech Social Security Administration (CSSA)}

First and foremost, CSSA carried out an executive role with respect to the calculation and disbursement of pension entitlements, and its crucial concern was to ensure sufficient time to prepare the calculation and disbursement of pensions in accordance with the newly approved provisions. In addition, CSSA raised awareness about the changes brought by the so-called Minor Pension Reform. It published a leaflet, "Minor Pension Reform in Questions and An swers", in which changes associated with the new law were summarised in a comprehensive manner for the general public.

\section{Actor constellation}

Shortly after the Constitutional Court's decision, the early election gave rise to a new right-centre government. There was a significant consensus among the coalition parties on the pension reform issue, in particular on the need to strengthen the degree of equivalence in the Czech Republic's the pension system.

The Expert Advisory Committee was established in 2010 with the main objective to analyse the current state of the pension system and suggest possible ways to reform it. As a possible solution to the situation, it proposed reducing the degree of solidarity in the state PAYG pillar, strengthening the degree of equivalence and monitoring its long-term fiscal sustainability.

The decision of the Constitutional Court, the outcomes of the parliamentary elections and the subsequently formed coalition government, and the rising professional discourse thus created favourable conditions for a rapid progress of preparation of changes to the pension formula to strengthen equivalence. Since none of the actors concerned questioned either the decision of the Constitutional Court itself or the need to implement it, the agenda of the day evolved around the manner in which that decision should be reflected within the wording of an amendment to the Act.

This seemingly technical question, however, had its significant economic connotations. Increasing the degree of equivalence for higher income categories within the pension formula would ceteris paribus lead to higher demands on the state budget. This, however, was not in accordance with the right-centre government's pledge to a fiscal stabilisation of the pension system. The task to propose the manner in which to combine within the pension system higher equivalence with fiscal stabilisation eventually fell on the shoulders of the MoLSA.

\section{Modes of interaction}

In the Czech Republic, single-party majority governments are not typical due to the proportional representation system. The institutional environment allows a government coalition to enforce its proposals in spite a possible disapproval by the second chamber of the Parliament (i.e. the Senate) or by the President of the Czech Republic, or even despite opposition from social partners. As a result, the governing elites do not necessarily have to seek a consensual style of policy making in a broader context.

As neither opposition parties nor the Czech-Moravian Confederation of Trade Unions liked the government's intention to strengthen the equivalence principle for higher income categories without increasing the burden on the state budget, it was obvious that the scope for a nation-wide consensus was narrowing. Despite debating the topic in the Council of Economic and Socia Agreement, the social partners did not show any efforts to find compromise solutions and there were no broad discussions. Claiming the reform had been "enforced" the Constitutional Court and under the pressure of its deadline, the government resorted to unilateral action and pushed through the amendment as its "proposed solution to the issue", against the opposition and without a consent of the Tripartite.

\section{ANALYSIS - PHASES OF THE POLICY CYCLE}

\section{Phase of problem delimitation and recognition}

In 2007, PM Mirek Topolánek formed a right-centre coalition of the Civic Democratic Party, the Christian and Democratic Union - Czechoslovak People's Party, and the Green Party. Pension reform was one of the key issues and tasks formulated in the government policy statement. One of the objectives of the so-called first stage of the pension reform was to strengthen individual responsibility and to implement parametric changes to the pension system towards strengthening the degree of equivalence and fiscal stabilisation. This way, the criterial foundation of the government's political choices was clearly established. 
Statements of the Chamber of Deputies, Senate and

MoLSA requested by the Constitutional Court

Following the above-mentioned proposal, the Constitutional Court sent the petition to individual parties to the proceeding. In accordance with Section 42 par. 3 and 4, and Section 69 of Act No. 182/1993 Coll., on the Constitutional Court, as amended, the Court requested responses to the petition from the Chamber of Deputies and the Senate of the Parliament of the Czech Republic, and requested also a written statement from the Ministry of Labour and Social Affairs (under Section 48 par. 1 and 2 of the Act on the Constitutional Court).

The Chamber of Deputies responded by a statement that within the legislative process of adopting the Act on Pension Insurance, which governs the setting of bend points, no factual objection to the section in question had been raised. The act was adopted following a duly executed legislative process.

The Senate stated that as a chamber of the Parliament of the Czech Republic, it was not yet constituted at the time the act in question was adopted (th first elections to the Senate were held in the fall of 1996). The Senate further stated that although the act had been amended several times, none of those former amendments related to the contested part of the act.

The statement of the MoLSA was more extensive. It has accentuated mainly the tradition of the institution of bend points in the Czech system of pension insurance (first established by Act No. 99/1948 Coll.), the fact that Act No. 155/1995 Coll. explicitly mitigated harshness in the system's settings, and a wide spectrum of degrees of equivalence that exist in the pension systems of other countries. In response to the plaintiff's interpretation of the function and nature of the institution of insurance, the Ministry distinguished between the social and private line of insurance, arguing that private insurance follows the principles stated in the complaint, while social insurance is designed differently. Bend points are, according to the MoLSA, an element that affects the degrees of equivalence and solidarity of the system of pension insurance and reflects legislators' preferences on how strongly these principles should be enshrined in the system. They are, therefore, a matter of political decision. Bend points strengthen solidarity and reduce the risk of poverty in the older generation, which is one of the fundamental objectives of the pension system.

\section{Decision of the Constitutional Court}

On 16 April 2010, in its decision Ref. No. Pl. ÚS 8/07, the Constitutional Court found the provision of Section 15 of Act No. 155/1995 Coll., on Pension Insur- ance, unconstitutional and abolished the so-called reduction limit for calculating the percentage assessment of a pension.

The Constitutional Court supported its decision, among other things, by the then only recently published expert opinions on the degrees of equivalence and redistribution in the Czech pension system. These reports had been formulated over a period of political discussions on the future direction of the pension system. The decision quoted the Final Report of the Expert Advisory Committee on strong income redistribution, suppression of insurance elements, and a relatively high contribution rate within the pension system of the Czech Republic (Final Report, 2010). Further in relied on the Actuarial Report on Social Insurance published regularly by the MoLSA, which described a possible pension system reform to diversify the system and strengthen the principle of equivalence (MoLSA, 2008). In the conclusion, the Constitutional Court stated that “... the entire complicated structure of the pension system is sufficiently non-transparent that it is de facto completely incomprehensible to its users; thus, for the majority of insured persons the calculated level of pension benefits becomes unverifiable."(Constitutional Court of the Czech Republic, 2010)

The Constitutional Court stated that "it is not its role to evaluate the correctness (suitability) of the calculation of pension insurance benefits". The Court should neither "evaluate the chosen pension system model from politica or economic viewpoints". Its judgement only assesses whether the construction of the pension system complies with the constitutional principles of the Czech Republic.

The decision by Constitutional Court was dissented by two constitutional judges: Jan Musil and Jiří Nykodým. Jan Musil argued that "the Constitutional Court stepped into the territory of social policy, decisions on which are reserved only to the legislature". Jiří Nykodým refused to perceive the degree of solidarity and thus also the degree of equivalence in social security systems as a constitutional issue. In his opinion it is an economic and especially politica question. It does not, in his opinion, relate to "a case of flagrant injustice", and only under such circumstances would it become a constitutional law question.

\section{Decision-making phase}

\section{Response to the decision of the Constitutional Court}

Given the contemporary political situation (early elections), the reactions of party leaders were suggestive of campaign rhetoric. Right-wing political parties interpreted the judgement as an affirmation of the need for pension reforms to strengthen the system's degree of equivalence. The chairman of the 
governing Civic Democratic Party, Petr Nečas, stated that the Court's decision was a confirmation of the fact that the current pension system was unsustainable. He challenged the bend points as egalitarian and suggested capping pension insurance premiums. He stressed the need to rapidly adopt pension reforms.

Left-wing political parties opposed the decision critically and drew attention to the danger of devaluing the principle of solidarity in social security systems. The chairman of the then strongest opposition party (Czech Social Democratic Party), Jiří Paroubek, labelled the Court's decision as activism, arguing it was not appropriate to its jurisdiction. Representatives of the Communist Party of Bohemia and Moravia perceived the judgment as directly challenging the preservation of the system's solidarity.

One of the more restrained statements that came to the fore was that of finance minister Eduard Janota, who expressed concern about a potential additional burden on the state budget.

The Czech-Moravian Confederation of Trade Unions opposed the judgment while promoting the value of solidarity. It was concerned about the "promotion" of reform concepts that reinforce the degree of equivalence at the expense of solidarity, moreover during the campaign before the elections to the Chamber of Deputies.

The preparation of a specific solution proposal took place after the elections. The new government was formed by a right-centre coalition of the Civic Democratic Party, the TOP 09 and the Public Affairs. What follows are propositions on the shape of the pension reform from the coalition partners' electoral programmes.
Civic Democratic Party: "We promote various forms of supplementary pension insurance and retirement savings, including greater involvement of employers and competition between pension plans. We propose a voluntary option to transfer a part of the premiums $(4 \%+$ a co-payment of $2 \%)$ to (private) pension funds."

(Electoral programme of the Civic Democratic Party, 2010)

TOP 09: "Within the second phase, the government will transform the pension system into a so-called multi-component system: PAYG (pay-as-yougo) - funded by compulsory pension insurance contributions of $28 \%$, or capitalisation - citizens can voluntarily opt for entering. In this case their contributions to the PAYG component will be reduced to $24 \%$, but they will be obliged to pay at least $6 \%$ to their capitalisation accounts. If one's parents are pension beneficiaries then 2 percent of his/her account will be assigned to them (...) The decline of revenue in the PAYG system will be compensated from assets of the CEZ Company ${ }^{1}$ and if necessary from indirect taxes." (Electoral programme of the TOP 09, 2010)

Public Affairs: "Given the current shape of the pension system, we propose a three-component pension system funded from the following sources: the existing PAYG funding from social security contributions, optional saving of $4 \%$ from social security contributions in a single state pension fund, and private commercial supplementary insurance."

(Electoral programme of the Public Affairs, 2010)

In its policy statement, the government responded directly to the situation caused by the decision of the Constitutional Court. It undertook to comply with the decision by proposing modifications to the construction of newly granted pensions and capping the assessment base for insurance premiums. The policy statement also included a broader outline of a pension reform to alleviate longterm financial unsustainability of the system.

\section{Proposal by the MoLSA}

In response to the decision of the Constitutional Court, the Ministry of Labour and Social Affairs put together three policy options - the so-called zero, formal and substantive solutions (Maška \& Rada, 2011).

Change in the pension benefit formula - The recommendation of the $\mathrm{MoLSA}^{3}$ was to implement changes only to the expenditure side of the pen-

3 Details of the proposal are described in the section on the phase of implementation. 
sion account. The Ministry proposed substantial revisions in the pension benefit formula designed for a neutral impact on the state budget. It also provided for a gradual "run-up" of the new formula during a transitional period from 2011 to 2015.

When discussing the adjustments proposed, critics focused mainly on additional parametric modifications. While the coalition parties pushed the amendment as a necessary step that was basically enforced by the decision of the Constitutional Court, opposition parties criticised mainly the impact of parametric adjustments on the amount of newly granted pensions for lower in come categories and a lack of debate over the proposed shape of the pension reform

The government submitted the draft amendment to the Chamber of Deputies on 2 March 2011. Critical responses to it stemmed mainly from two opposition parties - the Czech Social Democratic Party and the Communist Party of Bohemia and Moravia.

Czech Social Democratic Party: "The bill's response to the Constitutional Court decision is unjust, at the expense of middle-income earners. It will reduce newly awarded old-age pensions for $70 \%$ of policyholders (with monthly earnings ranging between 11 and 36 thousand CZK) in order to increase them for $10 \%$ of people with the highest earnings. This measure, along with the tightening of retirement conditions, has motivated a large number of applications for early retirement, which will cause an unintended rise of pension expenditure over the following years." (Minor Pension Reform is unfair, insensitive and illconceived, ČSSD strongly disagrees with it, 2011)

Communist Party of Bohemia and Moravia: "The impacts will be tough and antisocial. Seventy percent of new pensioners will see their pensions reduced by up to three percent. Twenty percent of new pensioners with the highest incomes will see their pensions increased by up to seven percent." (The impacts on people will be tough, 2011)

\section{Debate in the Chamber of Deputies}

Within the first reading that took place at the 14th session of the Chamber of Deputies on 15 March 2011, the then minister of labour and social affairs Jaromír Drábek (TOP 09) presented the amendment in the context of the necessity for a pension reform. There were additional parametric adjustments that went beyond mere response the decision of the Constitutional Court. In the debate, the proposal was supported by MP Jitka Chalánková (TOP 09) who considered the strengthening of the level of equivalence as the right step. Opposed to the proposal was MP Miroslav Opálka (Communist Party of Bohemia and Moravia) who described the proposed modifications as extremely harsh and antisocial. Prime Minister Petr Nečas (Civic Democratic Party) emphasised that the proposed changes were not so much an expression of one's political will as a response to the decision of the Constitutional Court. "The Constitutional Court wishes to strengthen the equivalence in the pension system." $\mathrm{He}$ described the amendment as an enforced decision.

The Committee on Social Policy discussed the bill and on 11 April 2011 recommended the proposal for approval without objections.

Within its second reading, the bill went through both general and detailed debate on 4 May 2011. Minister of labour and social affairs Jaromír Drábek repeated the argumentation from the first reading and discussed current trends that were fully in line with the parametric modifications proposed.

Bohuslav Sobotka (Czech Social Democratic Party) rejected the bill, arguing that it was not only a response to the decision of the Constitutional Court, but included additional parametric adjustments to the pension system that the government wanted approved. He criticised more extensively a proposed extension of the retirement age. The proposed modifications would affect the expenditure side of the pension account without strengthening the revenue side Prime Minister Petr Nečas (Civic Democratic Party) repeated his assertion that the amendments proposed responded to the decision of the Constitutional Court which required strengthening the principle of equivalence.

The third reading took place on 11 May 2011 and the bill was approved. In attendance were 136 MPs. 82 MPs of the government coalition or independent voted for the proposal, and 32 MPs, mostly from the Czech Social Democratic Party and the Communist Party of Bohemia and Moravia (plus one independent) voted against it

\section{Debate in the Senate}

The bill was tabled in the Senate on 17 May 2011. It was debated on 8 June 2011 and returned to the Chamber of Deputies with modifying proposals. The Senate proposed increasing the primary pension assessment from $9 \%$ to $10 \%$ to mitigate the slump caused by strengthening equivalence, and capping premiums at the level of five times the average earning instead of six to four times. 


\section{Decision of the Chamber of Deputies}

The document of the Senate was delivered to the Chamber of Deputies and distributed on 10 June 2011. In a vote on the bill returned by the Senate on 21 June 2011, the Chamber of Deputies upheld the original bill. In attendance were 176 MPs, 105 MPs from the governmental coalition voted for the bill, against it were 71 MPs (Czech Social Democratic Party, Communist Party of Bohemia and Moravia), while no independent MPs were logged in.

\section{President of the Czech Republic}

The amendment No. 220/2011 Coll. to Act No. 155/1995 Coll., on Pension Insurance, was delivered to the President for signature on 23 June 2011. The President expressed a dissenting opinion in which, among other things, he argued the constitutional judges had misunderstood the meaning and status of the pension system as a public good: "The state is neither a financial institution nor an insurance company, and pension insurance participants as well as recipients of state pensions are not its clients, as is very mistakenly believed by those Constitutional Court judges on whose initiative this amendment has been drafted. The principle of equivalence in this context has about as much sense as if each person paying significantly above-average taxes demanded, for example, that there should more streetlight to shine on him/her or wanted from the state a higher level of protection from the police compared to others." (Klaus, 2011). By 7 July 2011, the amendment to Act No. 155/1995 Coll., on Pension Insurance, had been neither signed into law by the president nor vetoed and sent back to the Chamber of Deputies. The coming into force of the Act remained unaffected by this procedure since the Constitution does not specifically require the President's signature on the Act. Nevertheless, legal experts agreed that the procedure was on the verge of constitutionality. ${ }^{4}$

\footnotetext{
4 "The Constitution uses the exact wording of 'Laws which have been enacted shall be signed', not 'has the right to sign' or 'may sign'. From this, commentaries infer a constitutional obligation to sign the act," says Jan Kysela from the Department of Legal Theory, Faculty of Law, Charles University. "Provided the President does not want to sign the act, he has the right to veto. If he does not want to veto the act, he has to sign it", he stated. For more details, see Macháček, D. Prezident nepodepsal zákon, porušil Ústavu? [The President did not sign the act, did he violate the from http://archiv.ihned.cz/c1-14318020-prezident-nepodepsal-zakon-porusil-ustavu.
}

\section{Phase of implementation}

\section{New wording of Section 15 of Act No.}

\section{5/1995 Coll., on Pension Insurance:}

1. During the period from 30 September 2011 to 31 December 2014, the calculation base shall be determined from the personal assessment base (Section 16) by adding up

a) $100 \%$ of the amount up to the first reduction limit

b) of the amount above the first reduction limit and up to the second reduction limit, 29\% during the period from 30 September 2011 to 31 December $2011,28 \%$ in 2012, 27\% in 2013 and $26 \%$ in 2014,

c) of the amount above the second reduction limit and up to the third reduction limit, 13\% during the period from 30 September 2011 to $31 \mathrm{De}-$ cember 2011, 16\% in 2012, 19\% in 2013 and $22 \%$ in 2014

d) of the amount above the third reduction limit, 10\% during the period from 30 September 2011 to 31 December 2011, 8\% in 2012, 6\% in 2013 and $3 \%$ in 2014.

2. In the period after the end of 2014 , the calculation base shall be determined from the personal assessment base (Section 16) by adding up

a) $100 \%$ of the amount up to the first reduction limit

b) $26 \%$ of the amount above the first reduction limit and up to the second reduction limit,

c) none of the amount above the second reduction limit.

3. During the period from 30 September 2011 to 31 December 2014, the first reduction limit shall be $44 \%$ of the average wage, the second reduction limit shall be $116 \%$ of the average wage and the third reduction limit shall be $400 \%$ of the average wage. In the period after the end of 2014, the first reduction limit shall be $44 \%$ of the average wage and the second reduction limit shall be $400 \%$ of the average wage for the calendar year. The reduction limits shall be rounded up to the nearest CZK.

Even before the reform came into force, CSSA has registered an extraordinary increase in the number of applications for early retirement. 66,458 people applied during the first 8 months of 2011, which was three times more than in 2010. Early retirement helped eliminate the negative impacts for those $80 \%$ for which the Minor Pension Reform would entail a reduction in the newly granted pension. In contrast, over the years following the amendment the number of pension applications among insured persons with a higher assessment base (for whom a postponement would mean more favourable calculation) did not show any significant fluctuations. 


\section{Phase of evaluation}

Although the theory of the policy cycle places the phase of evaluating public policies only after the implementation phase, in the present case we encountered an earlier assessment effort referred to in the literature as ex ante evaluation.

Ex ante assessment of impacts of the proposed amendments to the contested Section 15 was part of the RIA (Regulatory Impact Assessment) method adopted by the Ministry of Labour and Social Affairs. The key criteria for selecting an option were - as determined by the actor constellation identified an increase in the extent of equivalence and fiscal neutrality with regard to the long-term financial sustainability of the pension system.

The MoLSA conducted an ex ante evaluation of all three policy options (listed above in the paragraph on the decision making phase) on how to respond to the decision of the Constitutional Court and amend Section 15 of Act No. 155/1995 Coll., on Pension Insurance. Based on this evaluation, the MoLSA recommended implementing a variant of option 3 - adjustments only on the expenditure side of the pension account.

1) Zero solution (the provision in question would not be replaced). Pensions would be granted in their minimum amount. According to the assessment by the MoLSA this option would result in substantial savings to the pension system but the level of pensions would not at all be tied to the amount of insurance contributions paid. Removing the principle of equivalence would not materialise the purpose of the decision of the Constitutional Court.

2) Formal solution (to transform the existing insurance-based pension system into a social security system). According to the assessment by the MoLSA, this would be both legislatively demanding and time-consuming. In addition there was a threat that this solution could provoke accusations of circumventing the decision of the Constitutional Court. However, the balance of the primary pension account would be unaffected.

3) Substantive solutions:

- Modifications only to the expenditure side of the account. According to the MoLSA it was possible to draft proposals that did not create any additional pressure on the balance of the primary pension account.

- Modifications only to the revenue side of the account. This solution was not considered appropriate because the Constitutional Court in its decision had directly annulled Section 15 of the Act on Pension Insurance and therefore probably expected its amendment. This solution would require a significantly lower level of the maximum assessment base, namely around 24 times the average wage per calendar year. That would directly worsen the balance without the possibility of counter-balancing. The balance of the primary pension account would deteriorate.

- Combination of adjustments to the revenue and expenditure sides of the account. According to the MoLSA this measure would entail the risk of pressure on the pension account balance, at least during a transitional period due to timing discrepancy between effects on the revenue and expenditure sides.

The goal of strengthening equivalence in the pension system of the Czech Republic implied, within the context of the adopted reform proposal, an increase in the replacement rate for individuals with higher incomes. For example, individuals with incomes above CZK 36,000 per month saw their replacement rate increased from $29 \%$ to $36 \%$. The goal of maintaining solidarity without changing the level of the newly granted pensions was fulfilled only among lowincome individuals in the first decile $(10 \%$ of the insured with incomes of up to about CZK 10,900 per month). 70\% of the insured thus bore the costs of increasing the replacement rate for people with higher incomes by suffering reduced levels of pensions awarded using the new formula (a 2-6\% decrease of their replacement rate). For example, the replacement rate for individuals with incomes between the first and second reduction levels declined by up to $3 \%$.

Graph 1 Gross pension replacement rates by income deciles before and after reform

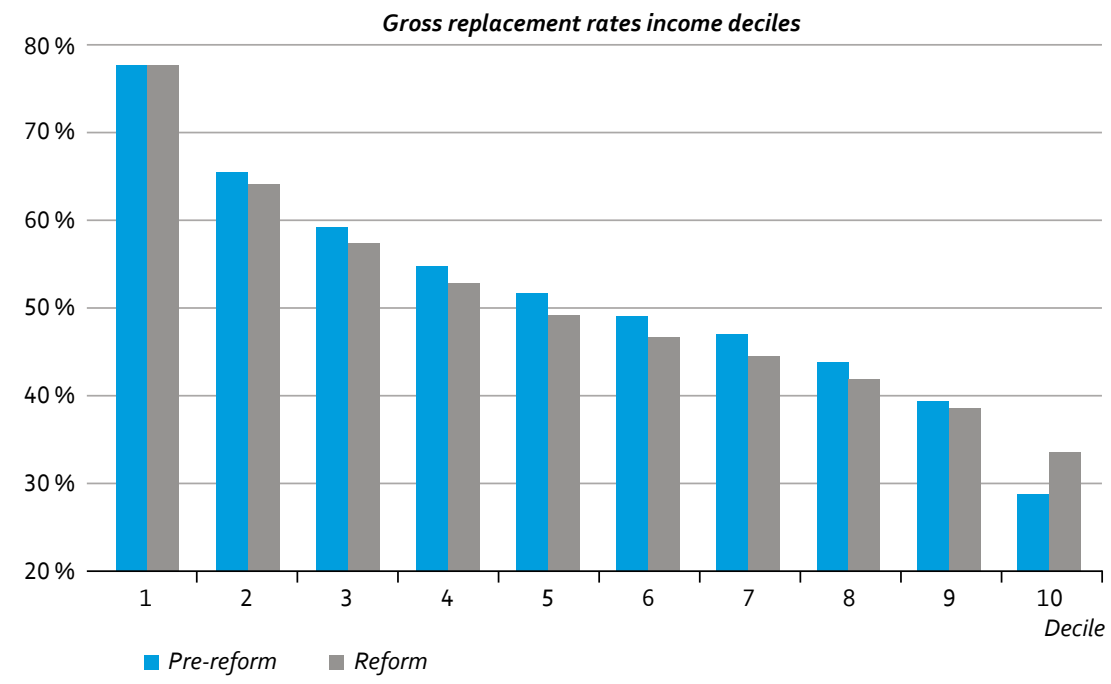

Source: Škorpik \& Suchomel, 2011. 
Graph 2 Gross replacement rate as a proportion of average wage before and after reform

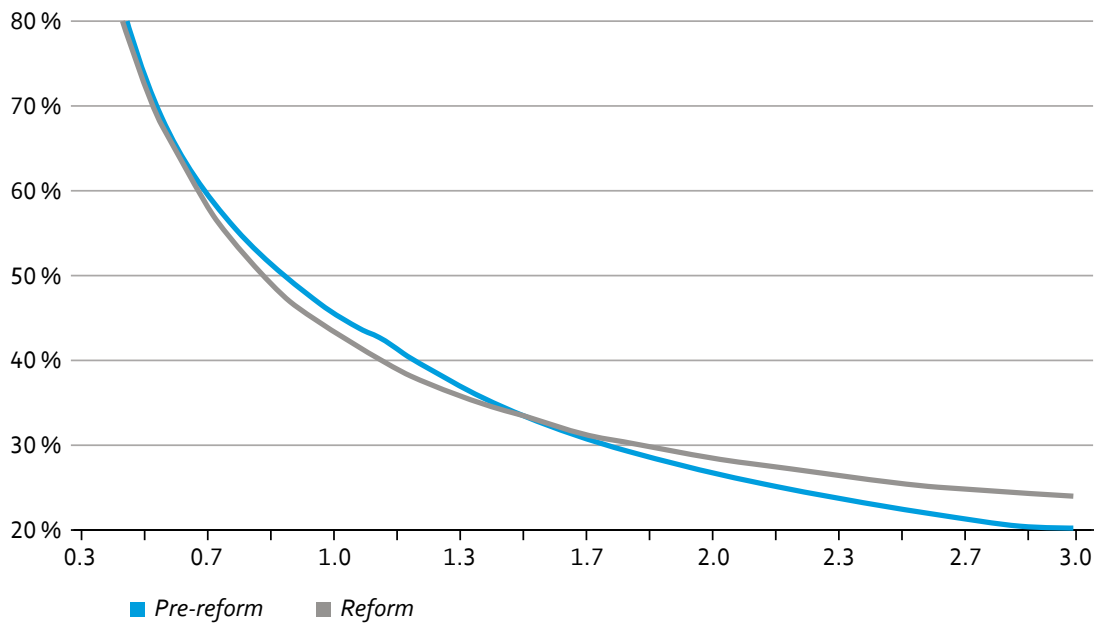

Source: Škorpik \& Suchomel, 2011

\section{CONCLUSION}

The theory of actor-centred institutionalism made the explanation of the policy process analysed more transparent. We proceeded from the institutional framework of the Constitution, which also defines the roles of key actors (the government, representative bodies, the Constitutional Court, the President) within the legislative process. We also reviewed the roles and options of other political actors (political parties, social partners, experts), and specified their constellations and modes of interaction. The theory also helped us identify the political symbolic of the actions of the President. Though he could not prevent the passing of a legislative act which he disapproved, he expressed his opinion at least through the act of "non-signature".

The theory of the policy cycle facilitated our understanding of the sequence of individual events, especially when looking at the legislative process itself. We were able to analyse public policy discourse in the phase of decision making where the theory of actor-centred institutionalism identified specific modes of interaction - in the given case confrontational rather than consensual ones. On the other hand, the policy cycle model did not correspond with the fact that (at least within the case analysed) the evaluation phase took place prior to the phases of decision making and implementation. Evaluation was re- flected already within both initial stages of the policy process: in the course of specifying and recognizing the issue by the plaintiff and subsequently by the Constitutional Court, and in the course of decision making, which was based both on the explicit demand made by the Constitutional Court (to increase equivalence) an on the implicit political criterion of the government (fiscal discipline to achieve sustainability of the pension system). It is important to add that our case study did not include an ex post assessment, which possibly could have started a new policy cycle. Nevertheless, the theories applied serve for an instructive demonstration of identifying key stakeholders and critical policy events.

\section{LIST OF ABBREVIATIONS}

\begin{tabular}{ll}
\hline CSSA & Czech Social Security Administration \\
\hline CZK & Czech Crown (national currency) \\
\hline ČMKOS & Czech-Moravian Confederation of Trade Unions \\
\hline ČR & Czech Republic \\
\hline CSSD & Czech Social Democratic Party (political party) \\
\hline KSČM & Communist Party of Bohemia and Moravia (political party) \\
\hline MPSV ČR & Ministry of Labour and Social Affairs of the Czech Republic (MoLSA) \\
\hline OECD & Organisation for Economic Co-operation and Development \\
\hline PČR & Parliament of the Czech Republic \\
\hline ÚS & Constitutional Court \\
\hline
\end{tabular}

\section{REFERENCES}

Bots, P.W.G. (2008) Analyzing actor networks while assuming "frame rationality". Paper presented at the conference on Networks in Political Science (NIPS). Kennedy School of Governance, Harvard University, Cambridge. [online] [quoted on June, 13-14, 2008]. Available from http://www.hks.harvard.edu/netgov/files/NIPS/PWG_BOTS_Analyzing_ actor_networks_14_June_2008.pdf

Burns, T.R., \& T. Baumgartner, Ph. Deville. (1985) Man, Decisions, Society: The Theory of Actor-System Dynamicsfor Social Scientists. New York: Gordon and Breach.

Constitutional Court of the Czech Republic. (2010) Decision of the Constitutional Court - Pl. ÚS 8/07. [online] [quoted on 23 March 2010]. Available from http://www.usoud.cz/en/ decisions/ 
ČMKOS (2011). Standpoint of ČMKOS. [online] Available from http://www.cmkos.cz/data/ articles/down_2829.pdf

Dopady na lidi budou tvrdé. [Impacts on people will be tough]. (2011). Haló noviny. Interview with the MP for KSČM Miroslav Opálka. 6 May 2011. [online] [quoted on 6 May 2011]. Available from http://www.halonoviny.cz/articles/view/22059.

Holub, M. (2010). Rozhodnutí Ústavního soudu nemusí nutně znamenat dramatický zásah do důchodového systému. [Decision of the Constitutional Court need not signify a dramatic intervention into the pension system.]. FÓRUM sociální politiky [FORUM of Social Policy], 4, pp. 16-20.

Holub, M. (2010). Solidarita versus ekvivalence v českém důchodovém pojištění pohledem Ústavního soudu. [Solidarity versus equivalence in the Czech pension insurance from the perspective of the Constitutional Court.]. FÓRUM sociálni politiky [FORUM of Social Policy], 3, pp. 19-20.

Howlett, M., \& Ramesh,M. (1995). Studying Public Policy: Policy Cycles and Policy Subsystems. Oxford: Oxford University Press.

Hupe, P. L., \& M. J. Hill. M. J. (2006). The Three Action Levels of Governance: Re-Framing the Policy Process Beyond the Stages Model. In B. G. Peters, J. Pierre. Handbook of Public Policy. (pp. 13-30). London: SAGE Publications.

Jaeger, C.C., Renn, O., Rosa, E.A., \& Webler, T. (2001) Risk, Uncertainty, and Rational Action. London: Earthscan Publications Ltd.

Klaus, V. (2011). Stát není pojištovna. [The state is not an insurance company]. MF DNES, 7 July 2011. [online] [quoted on 7 July 2011]. Available from http://www.klaus.cz/ clanky/2863.

Korpi, W. (2001). Contentious Institutions: An Augmented Rational-Actor Analysis of the Origins and Path Dependency of Welfare State Institutions in the Western Countries. Rationality and Society 13 (2): 235-83.

Lasswell, H. D. (1956). The Decision Process: Seven Categories of Functional Analysis. College Park, Maryland: University of Maryland.

Lindblom, C. E. (1968). The Policy-Making Process. Englewood Cliffs (NJ): Prentice-Hall.

Macháček, D. Prezident nepodepsal zákon, porušil Ústavu? [The President did not sign the act, did he violate the Constitution?] Hospodářské noviny, 4 May 2004. [online] [quoted on 4 May 2004]. Available online from http://archiv.ihned.cz/c1-14318020-prezidentnepodepsal-zakon-porusil-ustavu.

Mayntz, R., \& Scharpf, F. W. (Hrsg.). (1995). Gesellschaftliche Selbstregelung und politische Steverung. Frankfurt, Main: Campus.

Maška, J., \& Rada, J. (2011). Závěrečná zpráva Hodnocení dopadư regulace (RIA). [Final Report on Regulatory Impact Assessment (RIA)]. MPSV ČR.

MPSV. (2008). Pojistně matematická zpráva o sociálním pojištění. [Actuarial Report on Social Insurance] [online]. Available from http://www.mpsv.cz/files/clanky/5886/ zprava_2008_cz.pdf

Malá důchodová reforma je nespravedlivá, necitlivá a nedomyšlená, ČSSD s ní zásadně nesouhlasí. [Small Pension Reform is unfair, insensitive and ill-conceived, ČSSD strongly disagrees with it]. (2011). Press release by ČSSD. [online] [quoted on 12 May 2011]. Available from http://www.cssd.cz/systemove/neaktivni-nemazat-prevodstarych-aktualit/tiskove-zpravy/mala-duchodova-reforma-je-nespravedliva-necitlivaa-nedomyslena-cssd-s-ni-zasadne-nesouhlasi/.
OECD (2013). Pensions at a Glance 2013: OECD and G20 Indicators, OECD Publishing. [online] Available from http://dx.doi.org/10.1787/pension_glance-2013-en

Ovseiko, P. (2002). The Politics of Health Sector Reform in Eastern Europe: the Actor-Centred Institutionalist Framework for Analysis. Budapest: Center for Policy Studies. IPF Working Paper No. 2002-01.

Poradní expertní sbor. Závěrečná zpráva. (2010) [Expert Advisory Committee. Final Report.] [online]. Available from

http://www.mpsv.cz/files/clanky/8896/2010_06_03_Zaverecna_zprava_final_cistopis.pdf

Rahmatian, S., \& Hiatt, C.(1989). Toward an information-based theory of irrational systems behavior. Systems Research 6 (1).

Scharpf, F. W. (1997). Games Real Actors Play. Actor-Centred Institutionalism in Policy Research. Boulder: Westview Press.

Škorpík, J., \& Suchomel, M. (2011). The Czech Republic. In Kenichi HIROSE (ed.). Pension reform in Central and Eastern Europe: in times of crisis, austerity and beyond. Budapest. ILO. s. 157.[online] [2011]. Dostupné z http://www.ilo.org/public/english/region/eurpro/ geneva/download/pension reform cee.pdf

EXECUTIVE TEAM, Bezděk, V. (2005). Závěrečná zpráva - Reforma důchodů. [Final Report Reform of Pensions]. Praha, Online www.mpsv.cz/files/clanky/2235/zaverecna_zprava. pdf

Winkler, J. (2007). Teorie rozhodování a dynamika sociální politiky. [Decision Theory and Dynamics of Social Policy]. Brno: Masaryk University.

Yerkes, M.A. (2011). Transforming the Dutch Welfare State. Policy Press.

\section{LAWS}

Act No. 589/1992 Coll., on Social Security Premiums and Contributions to the State Employment Policy. In: Collection of Laws of the Czech Republic. Volume 1992.

Act No. 155/1995 Coll., on Pension Insurance. In: Collection of Laws of the Czech Republic. Volume 1995.

The Constitution of the Czech Republic. In Collection of Laws of the Czech Republic. 1992, Volume 1993, Part 1, Constitutional Act No. 1, pp. 2-16. Available also from www: <http://aplikace.mvcr.cz/sbirka-zakonu/ViewFile.aspx?type=z\&id=22427>.

The Charter of Fundamental Rights and Freedoms. In Collection of Laws of the Czech Republic. 1992, Volume 1993, Part 1, Resolution of the Presidium of the Czech National Council No. 2, pp. 17-23. Available also from www: <http://aplikace.mvcr.cz/ sbirka-zakonu/ViewFile.aspx?type=z\&id=22426> 